\title{
Erratum: Albort-Morant, G., et al. Potential and Realized Absorptive Capacity as Complementary Drivers of Green Product and Process Innovation Performance. Sustainability 2018, 10, 381
}

\author{
Gema Albort-Morant ${ }^{1,2, *}$, Jörg Henseler ${ }^{2,3}$, Gabriel Cepeda-Carrión ${ }^{4}[$ and \\ Antonio L. Leal-Rodríguez ${ }^{2,4}$ (D) \\ 1 Department of Social Sciences, Centro Universitario San Isidoro, 41092 Seville, Spain \\ 2 Faculty of Engineering Technology, University of Twente, 7500 AE Enschede, The Netherlands; \\ j.henseler@utwente.nl (J.H.); lealrodriguez@us.es (A.L.L.-R.) \\ 3 Nova Information Management School, Universidade Nova de Lisboa, 1070-312 Lisbon, Portugal \\ 4 Departamento de Administración de Empresas y Marketing, Universidad de Sevilla, 41018 Seville, Spain; \\ gabi@us.es \\ * Correspondence: galbort@centrosanisidoro.es
}

Received: 6 November 2018; Accepted: 2 January 2019; Published: 4 January 2019

The corresponding author wishes to make the following corrections to this paper [1]:

It has come to my attention that the paper [1] did not fully reference [2] and [3], two previous publications that I aim to fully attribute now. Sustainability author guidelines make it clear that any form of prior publication should be declared prior to submission. As corresponding author of both papers, I sincerely apologize for this.

In addition, I wish to offer a detailed explanation of the overlaps between these publications.

Overlaps between papers [1] and [2]: Although both publications are based in the same database, they entail substantial differences. While the research model published in [2] relies on second order (multidimensional) constructs, the research model posited in [1] entails a disaggregation of the constructs using the first order variables that form both constructs. Therefore, the objective of the model published in [1] is to deepen the knowledge of the relationships between the constructs in a disaggregated way. Consequently, the research hypotheses posited in [2] follow a "black box" approach, while in [1] the constructs are split into two dimensions, coherently with an open "black box" approach. This outcome contributes to enlarging the understanding of the non-linear linkages between the constructs being studied. In addition, the type of relationships hypothesized also vary between both papers.

Overlaps between papers [1] and [3]: Despite both publications being based in the same database and share one of the constructs (absorptive capacity), the two research models entail substantial differences, given that the rest of the constructs and relationships hypothesized significantly differ. Further, the dependent variable is different in both studies. The main similarity between these two publications is in the fact that both studies relied on the same scale to measure the absorptive capacity construct.

The authors wish to make the following corrections about the published paper [1]. The changes are as follows:

(1) Adding the paragraph in the last sentence of Section 5.1.

"Finally, the outcomes derived from this paper are in line with the findings comprised at $[75,76]$, although they comprise substantial differences, since the research model posited in this study entails a disaggregation of the main constructs using the first order variables that form both constructs. Therefore, the objective of this paper is to deepen the knowledge of the relationships between the 
constructs in a disaggregated way. Consequently, the research hypotheses posited follow an open "black box" approach. This outcome contributes to enlarging the understanding of the non-linear linkages between the constructs under investigation."

(2) Citing the following reference [2] in the main text, and treating it as reference 76 in the original paper.

Albort-Morant, G., Leal-Rodríguez, A. L., \& De Marchi, V. Absorptive Capacity and Relationship Learning Mechanisms as Complementary Drivers of Green Innovation Performance. J. Knowl. Manag. $2018,22,432-452$.

The corresponding author apologizes for any inconvenience caused to readers by these changes. The manuscript will be updated, and the original will remain online on the article webpage, with a reference to this addendum.

\section{References}

1. Albort-Morant, G.; Henseler, J.; Cepeda-Carrión, G.; Leal-Rodríguez, A.L. Potential and Realized Absorptive Capacity as Complementary Drivers of Green Product and Process Innovation Performance. Sustainability 2018, 10, 381. [CrossRef]

2. Albort-Morant, G.; Leal-Rodríguez, A.L.; De Marchi, V. Absorptive Capacity and Relationship Learning Mechanisms as Complementary Drivers of Green Innovation Performance. J. Knowl. Manag. 2018, 22, 432-452. [CrossRef]

3. Martelo-Landroguez, S.; Albort-Morant, G.; Leal-Rodriguez, A.L.; Ribeiro-Soriano, B. The Effect of Absorptive Capacity on Green Customer Capital under an Organizational Unlearning Context. Sustainability 2018, 10, 265. [CrossRef]

C 2019 by the authors. Licensee MDPI, Basel, Switzerland. This article is an open access article distributed under the terms and conditions of the Creative Commons Attribution (CC BY) license (http:/ / creativecommons.org/licenses/by/4.0/). 